IWONA ŻURASZEK-RYŚ

Uniwersytet Zielonogórski

\title{
POLSKIE HODONIMY UPAMIĘTNIAJĄCE I WOJNĘ ŚWIATOWĄ
}

W 2918 roku obchodzimy 100-lecie zakończenia I wojny światowej. Było to jedno z najdonioślejszych wydarzeń w dziejach naszej ojczyzny. Po wielu latach niewoli zrzuciliśmy obce jarzmo i odzyskaliśmy upragnioną wolność. Możliwe stało się utworzenie niepodległego państwa, a Polska znów mogła pojawić się na mapie politycznej Europy. Czy tak doniosły fakt historyczny znalazł odzwierciedlenie w nazwach ulic, alei, placów, osiedli polskich miast? Odpowiedź na to pytanie będzie stanowiła jeden z zasadniczych celów niniejszego artykułu. Istotne będzie również określenie typów nazw upamiętniających to ważne wydarzenie dziejowe.

Uzasadnieniem podjęcia zasygnalizowanego tematu może być fakt, że nazwy pamiątkowe, upamiętniające ważne osoby i wydarzenia dziejowe, stanowią dziś istotny składnik polskiego systemu nazewnictwa miejskiego. Na pewno warto je więc przybliżać. Jak pisała Kwiryna Handke: „[...] nazewnictwo miejskie jest wielką skarbnicą języka i kultury narodowej. Warto je poznawać i tłumaczyć. Warto też sięgać do życiorysów patronów ulic, żeby wiedzieć, kim byli ludzie, których postanowiono upamiętnić w nazewnictwie miasta, czym się zasłużyli dla miasta czy kraju, czy i dlaczego zyskali sławę światową" (Handke 2004: 97).

Materiał badawczy niniejszego opracowania stanowią hodonimy ${ }^{1}$ z 18 miast wojewódzkich Polski. Źródłem informacji o liczbie ulic opartych na konkretnym mianie była wyszukiwarka internetowa mapa.szukacz.pl ${ }^{2}$, natomiast o ich motywacji - publikacje, których opisy bibliograficzne zamieszczono w spisie literatury.

Z uwagi na ograniczenie materiału tylko do onimów z miast wojewódzkich pracę należy traktować jako wstępną analizę przywołanego w tytule zagadnienia.

1 Hodonim - nazwa własna drogi, zwykle miejskiej (ulicy), także placu, skweru, drogi krajowej, autostrady, tunelu itp. (za: w1).

${ }^{2}$ Mapa.szukacz.pl to interaktywna mapa Polski, której zasoby stanowią dane o położeniu i przynależności administracyjnej 913 miast (tyle polskich miejscowości miało prawa miejskie na początku 2014 roku) i 50 tysięcy wsi i osiedli wiejskich, a także dane o położeniu ponad 100 tysięcy ulic oraz tysiąca stacji kolejowych (dostęp: 24.03.2018). 
Sama określenie I wojna światowa nie pojawia się w polskiej urbanonimii. Być może jest to podyktowane analogią do nazwy II wojna światowa, mającej zbliżoną postać i odnoszącej się do wydarzenia o podobnej randze - również ważnego w dziejach Polski, a przez wiele lat - bardziej eksponowanego przez władze komunistyczne. Z drugiej jednak strony, istotniejszy dla Polaków był pewnie efekt I wojny światowej - odzyskanie po wielu latach zaborów upragnionej niepodległości. Według wyszukiwarki internetowej w każdym z miast wojewódzkich znajduje się hodonim motywowany wyrazem niepodległość. Są to nazwy ulic, alei i placów. Odnotowano również nazwę ronda w Gorzowie Wielkopolskim i Toruniu, a także wiaduktu w Bydgoszczy. Warto przy okazji dodać, że w niektórych miastach znajduje się więcej onimów opartych na tej podstawie, np. w Białymstoku jest aleja Niepodległości i ulica Niepodległości, w Gorzowie Wielkopolskim - ulica Niepodległości i rondo Niepodległości, w Krakowie - plac Niepodległości i ulica Niepodległości. Przywołane przykłady wskazują, że toponimy miejskie z określeniem niepodległość są bardzo popularne. Należy jednak zaznaczyć, że nie wszystkie miana wskazane przez wyszukiwarkę internetową odnoszą się do faktu z 1918 roku. Na przykład plac Niepodległości w Łodzi, jak podają autorki Nazewnictwa miejskiego Łodzi, upamiętnia odzyskanie przez miasto wolności w 1945 roku (Bieńkowska, Umińska-Tytoń 2013: 111). Do odzyskania niepodległości z 1918 roku nawiązuje natomiast plac Wolności: „Po walkach w listopadzie 1918 r. stoczonych na terenie placu z niemieckimi żołnierzami zyskał w 1919 r. dla uczczenia pierwszej rocznicy uwolnienia Polski od najeźdźców nazwę plac Wolności” (Bieńkowska, Umińska-Tytoń 2013: 175).

Według wyszukiwarki internetowej hodonimy motywowane wyrazem wolność znajdują się w trzynastu miastach wojewódzkich. Są to: pięć nazw ulic (Gdańsk, Katowice, Kraków, Opole, Warszawa) i dziewięć nazw placów (Bydgoszcz, Katowice, Kielce, Lublin, Łódź, Poznań, Rzeszów, Szczecin, Wrocław). W Katowicach jest zarówno plac Wolności, jak i ulica Wolności. I tak jak w przypadku wyżej wymienionej niepodległości, trzeba być ostrożnym w ustaleniu motywacji onimów na podstawie samych zapisów wskazanych przez wyszukiwarkę internetową. Część z nich będzie się bowiem odnosić do odzyskania niepodległości w 1918 roku (na przykład plac Wolności w Bydgoszczy nawiązuje - jak podają autorki Słownika toponimów miejskich Bydgoszczy - „do wkroczenia do Bydgoszczy pierwszych polskich oddziałów wojskowych, saperów pod dowództwem ppłk. Witolda Butlera, które przerodziło się w patriotyczną manifestację mieszkańców miasta" - Czachorowska, Czaplicka-Jedlikowska, Jaracz, Paluszak-Bronka 2008: 224), a część - do odzyskania wolności po zakończeniu II wojny światowej, na przykład plac Wolności w Krakowie upamiętniał wkroczenie do miasta w styczniu 1945 roku wojsk radzieckich. Jak podaje Elżbieta Supranowicz w 1991 roku zastąpiono tę nazwę placem Inwalidów (Supranowicz 1995: 62).

Z I wojną światową kojarzy się też 11 listopada. Tego dnia 1918 roku podpisano akt kapitulacji Niemiec i tym samym doszło do zakończenia wojny, a wraz z nim - do ziszczenia marzenia Polaków o wolności. Tego też dnia przekazano Józefowi Piłsudskiemu naczelne dowództwo nad siłami zbrojnymi. Rozpoczął się kolejny rozdział w polskiej historii. 11 listopada więc to data szczególna w historii Polski, uznawana za święto niepodległości. Znalazła ona odzwierciedlenie w hodonimach $\mathrm{z}$ jedenastu miast wojewódzkich: dziewięciu ulicach (Białystok, Bydgoszcz, Gdańsk, Katowice, Lublin, Łódź, Olsztyn, Opole, Warszawa), jednej alei (Gorzów Wielkopolski) i jednym rondzie (Zielona Góra). 
Wśród onimów utworzonych od dat i nazw faktów historycznych należy wspomnieć jeszcze o 6 sierpnia 1914 roku, kiedy doszło do wymarszu z Oleandrów I Kompanii Kadrowej Strzelców. To wydarzenie zostało upamiętnione w nazwie ulicy w Łodzi i Warszawie.

Do wyżej wskazanej grupy należy włączyć także hodonimy odnoszące się do walk stoczonych w czasie I wojny światowej. Na przykład bitwa pod Rokitną została upamiętniona w nazwie warszawskiej ulicy - ul. Bitwy pod Rokitna. W Warszawie znajduje się także ulica związana z walkami pod Krechowcami (ul. Krechowiecka). Przed II wojną światową w stolicy był też hodonim upamiętniający bitwę pod Rarańczą (ul. Rarańczy obecnie ul. Or-Ota).

Wśród nazw miejskich upamiętniających wydarzenia historyczne wyodrębnia się również formy oparte na nazwach formacji i organizacji wojskowych.

W analizowanym materiale, dotyczącym onimów związanych z I wojną światową, odnotowano na przykład następujące formy reprezentujące tę kategorięę:

- Legionów (również Legionów Piłsudskiego, Legionów Polskich) - nazwa odnosząca się do legionów - formacji wojskowych z lat 1914-1917, wywodzących się z oddziałów strzeleckich - polskich organizacji wojskowo-niepodległościowych. W sierpniu 1914 roku utworzono Legion Wschodni i Legion Zachodni, a jesienią połączono je w Legiony Polskie. Ta formacja wojskowa została upamiętniona w hodonimach zarówno w postaci skróconej, zawierającej tylko nazwę legion (np. al. Legionów w Kielcach), jak i rozbudowanej o przydawkę polski (np. ul. Legionów Polskich w Gorzowie Wielkopolskim), a także zawierającej informację o ideowym przywódcy legionów i ich dowódcy - Piłsudskim (np. ul. Legionów Józefa Piłsudskiego w Krakowie).

- Polskiej Organizacji Wojskowej - nazwa odwołująca się do grupy założonej z inicjatywy J. Piłsudskiego w 1914 roku w Warszawie przez członków organizacji strzeleckich. Działała ona w Królestwie Polskim, potem także w Galicji, na Ukrainie i w Rosji. Po kryzysie przysięgowym funkcjonowała w konspiracji przeciw zaborcom austriackim i niemieckim. Nazwa tej formacji została upamiętniona w nazwie łódzkiej ulicy.

- Ułanów Krechowieckich - nazwa odnosząca się do polskiego oddziału kawalerii, utworzonego w 1915 roku w ramach I Legionu Polskiego (tzw. Legionu Puławskiego). Swój przydomek zawdzięcza miejscowości Krechowce niedaleko Stanisławowa, gdzie pod dowództwem płk. Mościckiego stoczył swój pierwszy zwycięski bój. Nazwa tej formacji została utrwalona w nazwie ulicy w Szczecinie i Warszawie.

Przedstawione powyżej hodonimy, oparte na określeniach formacji i organizacji wojskowych, nie stanowią zbyt licznej grupy. Zdaniem Kwiryny Handke nie są to formy pożądane m.in. ze względu na ich rozbudowaną postać: „W rezultacie mamy do czynienia z napisami pomnikowymi, a nie z użytkowymi czy symbolicznymi deskrypcjami obiektów funkcjonujących w przestrzeni miasta. Nie trzeba specjalnie podkreślać, że ich praktyczne stosowanie w pełnym brzmieniu w codziennej komunikacji językowej nie jest możliwe i że mówiący są zmuszeni do rozmaitych zabiegów redukujących część składników tak brzmiących nazw" (Handke 1998: 41).

${ }^{3}$ Informacje o zaprezentowanych formacjach i organizacjach wojskowych pochodzą z 15, 21 i 28 tomu Wielkiej encyklopedii PWN (zob. WE). 
Obok onimów, odwołujących się do nazw formacji i organizacji wojskowych, można także wskazać hodonimy odnoszące się do patronów grupowych, np. ul. Walecznych, ul. Obrońców, ul. Zwycięzców. Według wyszukiwarki internetowej ul. Walecznych znajduje się w ośmiu miastach wojewódzkich (Bydgoszcz, Gdańsk, Kraków, Lublin, Olsztyn, Szczecin, Warszawa, Wrocław), ul. Obrońców - w dwóch miastach wojewódzkich (Olsztyn, Warszawa), a ul. Zwycięzców - w jednym mieście wojewódzkim (Warszawa). Nazwy te nie we wszystkich jednak miastach stanowią uhonorowanie bohaterów I wojny światowej. Na pewno w Warszawie nawiązują do czasów I wojny światowej i walk o niepodległość.

Pewien rodzaj upamiętnienia I wojny światowej stanowią ponadto nazwy miejskie oparte na antroponimach. Onimy motywowane nazwiskami osób, które uczestniczyły w tej wojnie, walcząc lub podejmując działania dyplomatyczne na rzecz odzyskania przez Polskę niepodległości, należy podzielić na dwie kategorie. Pierwszą będą stanowiły hodonimy upamiętniające postaci za ich dokonania w czasie I wojny światowej, a więc żołnierzy i dowódców legionów, uczestników działań zbrojnych, drugą natomiast formy upamiętniające postaci biorące udział w I wojnie światowej, ale zasłużone dla miasta bądź ojczyzny także z jakiegoś innego ważnego powodu. Z tego też względu nazwy te należy traktować jako pośrednio związane $\mathrm{z}$ omawianym zagadnieniem.

Wśród nazw zaliczonych do pierwszej grupy należy wskazać formy oparte na następujących postaciach:

- Tadeusz Furgalski-Wyrwa (1890-1916) - w czasie I wojny światowej służył w Legionach Polskich i odznaczył się w wielu bitwach, m.in. pod Konarami, Kostiuchnówką. Zginął w czasie odwrotu z tej ostatniej walki. Nazwa ulicy motywowanej jego nazwiskiem znajduje się w Krakowie.

- Edward Gibalski (1886-1915) - bojowiec PPS, żołnierz legionów. 13 września 1915 roku oddział E. Gibalskiego dostał się w Stobychwie w zasadzkę, a sam E. Gibalski został ciężko ranny i zmarł podczas transportu do Kowla. Ulice upamiętniające tę postać znajdują się w dwóch miastach wojewódzkich: Łodzi i Warszawie.

- Leopold Lis-Kula (1896-1919) - legionista, niezwykle odważny żołnierz, biorący udział w walkach m.in. pod Kielcami, na Lubelszczyźnie. Po kryzysie przysięgowym został wcielony do armii austriackiej i wysłany na front włoski. Po powrocie do kraju zajął się tworzeniem polskich sił zbrojnych na Wschodzie. Jego nazwisko stało się podstawą ulic znajdujących się w Krakowie, Rzeszowie i Warszawie.

- Stanisław Mitera (1890-1915) - po wybuchu wojny wstąpił do legionów. Został dowódcą kompanii podczas działań na Wołyniu. Poległ 22 listopada 1915 roku w okopach pod Kostiuchnówką. Ulica upamiętniająca tę postać znajduje się w Krakowie.

- Franciszek Pększyc (1891-1915) - zaraz po wybuchu wojny został wysłany na front serbski, skąd zdezerterował i przedostał się do Galicji. Przyjąwszy pseudonim Grudziński, wstąpił do Legionów Polskich. W czasie wojny dał się poznać jako wymagający dowódca, dbający o wyszkolenie podległych mu żołnierzy. Został ciężko ra-

${ }^{4}$ Informacje o prezentowanych osobach pochodzą z następujących źródeł: NEP, WE, WEP, Cygan 1992, Wrzosek 1990. W biogramach zwrócono uwagę głównie na dokonania prezentowanych osób w czasie I wojny światowej. 
niony w czasie patrolu pod Modliborzycami i dobił się wystrzałem z pistoletu. Nazwa ulicy utworzona od nazwiska i pseudonimu tej postaci znajduje się w Krakowie (ul. Pększyca-Grudzińskiego).

- Kazimierz Piątek (1886-1915) - w czasie I wojny światowej służył w Legionach Polskich. Był dowódcą I Kompanii Kadrowej, a następnie - 2 Batalionu 1 Pułku Piechoty i 5 Batalionu I Brygady. Zmarł wskutek ran odniesionych w walce o wzgórze Kozinek-Płaczkowice pod Konarami w 1915 roku. Jego nazwiskiem oraz pseudonimem nazwano jedną z krakowskich ulic (ul. Herwina-Piątka).

- Zbigniew Wąsowicz-Dunin (1882-1915) - brał udział w pierwszych walkach w rejonie Kielc. Następnie na czele sformowanego przez siebie szwadronu kawalerii wyruszył na front karpacki. Poległ 13 czerwca 1915 roku pod Rokitną. Jego postać upamiętniają nazwy ulic w Krakowie i Warszawie.

- Tadeusz Żuliński (1889-1915) - był adiutantem Piłsudskiego. Brał udział w kampanii kieleckiej i w walkach nad Wisłą. W 1915 roku został wyznaczony na komendanta głównego POW. W Warszawie zorganizował baon POW, na czele którego wyruszył na front. Podczas bitwy pod Kamieniuchą został ciężko ranny i zmarł parę dni później wskutek odniesionych ran. Ulica upamiętniająca tę postać znajduje się w Warszawie.

Wśród osób, których nazwisko stało się podstawą hodonimów zaliczonych do drugiej grupy, należy wskazać przede wszystkim Józefa Piłsudskiego, uznawanego za wskrzesiciela niepodległego państwa. W czasie I wojny światowej dowodził wojskiem, które dzielnie walczyło m.in. w Kieleckiem, a także nad Dunajcem i Nidą. Odniósł kilka efektownych zwycięstw na froncie, m.in. pod Konarami i Ożarowem, Kostiuchnówką, nad Styrem i Stochodem. Uważany był za ideowego przywódcę legionów, a później całego narodu polskiego. Jak możemy przeczytać w encyklopedii: „Lata konspiracji, a następnie okres legionowy ujawniły niezwykłą, wręcz charyzmatyczną osobowość Piłsudskiego; jego rosnący autorytet oddziaływał na najbliższych współpracowników" (WE 2004: 65). Odmowa złożenia przysięgi na wierność cesarzom Austrii i Niemiec oraz jego zdecydowana postawa wobec zaborców jeszcze ten autorytet umocniły. Piłsudski stał się więc w oczach społeczeństwa polskiego symbolem konsekwentnych dążeń niepodległościowych. Jego osoba została upamiętniona w nazwach różnych obiektów miejskich (ulic, alei, placów, rond czy mostów) z siedemnastu miast wojewódzkich (nie ma tylko w Gdańsku). W ośmiu z nich funkcjonuje kilka hodonimów odnoszących się do tej postaci, np. w Krakowie - ul. Józefa Pitsudskiego i most Józefa Pitsudskiego; we Wrocławiu - ul. Józefa Piłsudskiego i plac Józefa Pitsudskiego. Warto też zwrócić uwagę na formę tych nazw. Niektóre występują w pełnej postaci (tzn. złożonej z imienia i nazwiska) - ul. Józefa Piłsudskiego, często jeszcze uzupełnionej o tytuł - ul. Marszałka Józefa Piłsudskiego (tytuł Marszałka Polski otrzymał później, po zajęciu Kijowa), a część w postaci skróconej (tzn. złożonej tylko z nazwiska) - ul. Pitsudskiego.

Do drugiej grupy onimów należy zaliczyć także nazwy odnoszące się do żołnierzy i dowódców, biorących udział nie tylko w I wojnie światowej, ale i innych wojnach (np. polsko-bolszewickiej czy II wojnie światowej) $)^{5}$ :

${ }^{5} \mathrm{~W}$ pracy przywołano postaci, które najczęściej (tzn. przynajmniej trzy razy) odnotowano w podstawie hodonimów z polskich miast wojewódzkich. 
- Władysław Belina-Prażmowski (1888-1938) - twórca i dowódca kawalerii legionowej, pułkownik. Na początku wojny dowodził siedmioosobowym patrolem, grupą zwiadowczą, poprzedzającą pierwszą kompanię kadrową w jej marszu do Królestwa Polskiego. W latach 1914-1917 był oficerem Legionów Polskich, następnie został mianowany majorem, a w 1918 roku - pułkownikiem. Uczestniczył w wielu walkach, m.in. pod Łowczówkiem, Konarami, Włostowem, Urzędowem. W lipcu 1917 roku został zdymisjonowany za odmowę złożenia przysięgi. Nazwy motywowane tą postacią dotyczą określeń ulicy i znajdują się w trzech miastach wojewódzkich: Krakowie, Toruniu i Warszawie.

- Józef Dowbor-Muśnicki (1867-1937) - na początku wojny awansował na dowódcę pułku, a następnie - dywizji piechoty. Brał udział w wielu walkach i w 1917 roku został mianowany generałem lejtnantem, a potem - dowódcą Korpusu Polskiego w Rosji (tzw. dowborczyków). Początkowo chciał zachować neutralność wobec walczących sił w Rosji, później jednak zgromadził kilkadziesiąt tysięcy polskich żołnierzy, służących dotychczas w wojsku rosyjskim, i walczył z nimi przeciwko bolszewikom. W 1918 roku podporządkował Korpus Radzie Regencyjnej, a pod wpływem niemieckim doprowadził do jego demobilizacji. Nazwy ulic motywowane tą postacią znajdują się tylko w Polsce zachodniej (Bydgoszcz, Gorzów Wielkopolski, Poznań), dlatego nie można wykluczyć, że główną motywacją w wyborze tej postaci były jej zasługi w czasie powstania wielkopolskiego.

- Stanisław Grzmot-Skotnicki (1894-1939) - generał; w latach 1914-1917 był w Legionach Polskich, internowany w Beniaminowie. Jego postać upamiętniają nazwy ulic z trzech miast wojewódzkich: Bydgoszczy, Poznania i Wrocławia.

- Józef Haller (1873-1960) - generał, polityk. W czasie wojny dowodził najpierw legionami, które dzielnie walczyły w Karpatach Wschodnich, na granicy galicyjsko-węgierskiej i na Bukowinie. Nie godząc się z ustaleniami poczynionymi w Brześciu, przedarł się przez front austriacko-rosyjski pod Rarańczą i połączył z polskimi formacjami w Rosji. W 1918 roku został mianowany na generała. Po przegranej bitwie z Niemcami pod Kaniowem przedostał się do Moskwy, gdzie stanął na czele Polskiej Komisji Wojskowej. Następnie wyjechał do Francji i został członkiem Komitetu Narodowego Polskiego, który powierzył mu naczelne dowództwo nad formującym się wojskiem polskim. Nazwisko tej postaci stało się podstawą hodonimów w czternastu miastach wojewódzkich Polski: Bydgoszczy, Gdańsku, Gorzowie Wielkopolskim, Katowicach, Krakowie, Lublinie, Łodzi, Olsztynie, Opolu, Poznaniu, Szczecinie, Toruniu, Warszawie i Wrocławiu. Są to przede wszystkim nazwy ulic (10). Ponadto wyszukiwarka podaje dwie nazwy alei i dwie nazwy placów.

- Michał Karaszewicz-Tokarzewski (1893-1964) - generał; w latach 1914-1917 był w Legionach Polskich (m.in. dowódca 5 Pułku Piechoty w 1917 roku), po kryzysie przysięgowym internowany przez władze niemieckie, następnie w POW i armii austriackiej. Ulice upamiętniające tę postać znajdują się w trzech miastach wojewódzkich: Krakowie, Toruniu i Warszawie.

- Franciszek Kleeberg (1888-1941) - generał, w latach 1915-1917 był w Legionach Polskich (zastępca dowódcy 1. pułku artylerii w 1917 roku), następnie w Polskiej Sile Zbrojnej; w 1918 roku odwołany do armii austriackiej i karnie skierowany na front włoski za złożenie prośby o zmianę obywatelstwa na polskie. Nazwy ulic mo- 
tywowane tą postacią znajdują się w dwunastu miastach wojewódzkich: Białymstoku, Bydgoszczy, Gorzowie Wielkopolskim, Kielcach, Krakowie, Lublinie, Łodzi, Olsztynie, Poznaniu, Szczecinie, Warszawie i Wrocławiu.

- Edward Rydz-Śmigły (1886-1941) - działacz niepodległościowy, marszałek Polski. W czasie I wojny światowej służył w Legionach Polskich. Był m.in. dowódcą 1 Pułku Piechoty, następnie (w 1915 roku) - dowódcą I Brygady. Po aresztowaniu Piłsudskiego i Sosnkowskiego objął kierownictwo nad Polską Organizacją Wojskową. Jego postać upamiętniają hodonimy z czterech miast wojewódzkich. Są to trzy nazwy ulic (Kraków, Wrocław, Zielona Góra) i jedna nazwa alei (Łódź).

- Władysław Sikorski (1881-1943) - w czasie I wojny światowej walczył w Legionach Polskich. Był szefem departamentu wojskowego w Naczelnym Komitecie Narodowym. Po kryzysie przysięgowym został wcielony do armii austro-węgierskiej. Następnie za potępienie traktatu brzeskiego został oskarżony o zdradę stanu i internowany. Po wyjściu z więzienia przystąpił do formowania wojska polskiego na terenie Galicji. Hodonimy odnoszące się do tej postaci znajdują się w każdym mieście wojewódzkim (przy czym w Warszawie i Wrocławiu są dwie nazwy oparte na tym nazwisku), w dwunastu - są to nazwy ulic. Ponadto odnotowano także pięć nazw alei i po jednym określeniu: placu, mostu i wału.

- Stanisław Sosabowski (1892-1967) - generał; podczas I wojny światowej w armii austriackiej i POW. Jego postać upamiętniają nazwy ulic z czterech miast wojewódzkich: Białegostoku, Gorzowa Wielkopolskiego, Szczecina i Warszawy.

- Kazimierz Sosnkowski (1885-1969) - w czasie I wojny światowej służył w legionach, walcząc dzielnie w obronie ojczyzny i zastępując nawet kilkakrotnie w dowodzeniu nieobecnego Piłsudskiego. Pełnił też funkcję szefa sztabu I Brygady Legionów Polskich. W 1916 roku został usunięty przez Austriaków z Legionów Polskich za działalność niepodległościową. W 1917 roku został szefem departamentu wojskowego Tymczasowej Rady Stanu. W lipcu tego samego roku wraz z Piłsudskim i szeregiem innych osób został aresztowany przez Prusaków, a następnie osadzony w twierdzy w Magdeburgu. Nazwy motywowane nazwiskiem tej postaci dotyczą tylko nazw ulic i znajdują się w siedmiu miastach wojewódzkich: Gdańsku, Gorzowie Wielkopolskim, Krakowie, Olsztynie, Opolu, Wrocławiu i Warszawie.

W grupie drugiej obok żołnierzy i dowódców należy też wskazać polityków i przedstawicieli innych profesji:

- Józef Beck (1894-1944) - dyplomata, polityk, pułkownik. Podczas I wojny światowej w Legionach Polskich, a od 1917 roku - w POW na Ukrainie i w Rosji. Hodonimy upamiętniające tę postać znajdują się w trzech miastach wojewódzkich. Są to dwie nazwy ulic (Kraków, Wrocław) i jedna nazwa alei (Warszawa).

- Ignacy Daszyński (1866-1936) - polski polityk socjalistyczny, cieszący się sławą dobrego mówcy i agitatora. Był członkiem Naczelnego Komitetu Narodowego. Przyczynił się do powstania Legionów Polskich. Uczestniczył w pracach nad konstytucją Królestwa Polskiego, a następnie nad wnioskiem skierowanym do parlamentu austriackiego, w którym domagano się utworzenia niepodległego państwa polskiego, złożonego z ziem należących do trzech zaborów, z własnym dostępem do morza. Jego osobę upamiętniono w hodonimach z trzynastu miast wojewódzkich (przy czym w Opolu są dwie nazwy oparte na tym nazwisku). Są to: dziewięć nazw 
ulic (Bydgoszcz, Gorzów Wielkopolski, Katowice, Kielce, Lublin, Opole, Poznań, Szczecin, Wrocław), trzy nazwy placów (Olsztyn, Opole, Toruń) oraz po jednej nazwie alei (Kraków) i ronda (Warszawa).

- Roman Dmowski (1864-1939) - polityk, mąż stanu. Po wybuchu I wojny światowej przebywał w Petersburgu i opowiadał się za polityką ugodową wobec Rosji. W związku z zmianą sytuacji w tym kraju, wyjechał do Europy Zachodniej, gdzie zabiegał o utworzenie niepodległego państwa polskiego. W celu nadania swoim działaniom charakteru formalnego, powołał w Paryżu Komitet Narodowy Polski. Z jego inicjatywy zorganizowano we Francji wojsko polskie, na czele którego stanął gen. Józef Haller. Nazwy motywowane nazwiskiem tej postaci znajdują się w trzynastu miastach wojewódzkich (przy czym w Lublinie i Wrocławiu są dwie nazwy oparte na tym nazwisku). Są to: dziewięć nazw ulic (Bydgoszcz, Gdańsk, Gorzów Wielkopolski, Kraków, Lublin, Opole, Poznań, Szczecin, Wrocław), cztery nazwy rond (Lublin, Rzeszów, Warszawa, Zielona Góra) oraz po jednej nazwie mostu (Wrocław) i placu (Łódź).

- Władysław Grabski (1874-1938) - polityk, ekonomista, znany reformator walutowy. W czasie I wojny światowej był członkiem Komitetu Narodowego Polskiego. Założył Centralny Komitet Obywatelski w Warszawie, a po wyjeździe do Rosji (z powodu wkroczenia Niemców do Warszawy) - nadal działał w tej organizacji, pełniąc funkcję głównego pełnomocnika. Udzielał się też w Polskim Towarzystwie Pomocy Ofiarom Wojny. Organizował pomoc dla ludności polskiej w zaborze rosyjskim i reprezentował interesy Polski w Rosji. Po wybuchu rewolucji październikowej oraz zawarciu pokoju brzeskiego wrócił do Polski i został aresztowany przez Niemców, a następnie osadzony w twierdzy w Modlinie. Wyszedł stamtąd w 1918 roku. Nazwy ulic upamiętniające tę postać znajdują się w sześciu miastach wojewódzkich: Gorzowie Wielkopolskim, Katowicach, Lublinie, Rzeszowie, Toruniu, Wrocławiu.

- Eugeniusz Kwiatkowski (1888-1974) - polityk, działacz gospodarczy, inżynier chemik; od 1916 roku był w Legionach Polskich i POW. Jego postać upamiętniają nazwy ulic z dwunastu miast wojewódzkich: Bydgoszczy, Gdańska, Gorzowa Wielkopolskiego, Katowic, Krakowa, Lublina, Opola, Poznania, Rzeszowa, Szczecina, Warszawy i Wrocławia.

- Ignacy Paderewski (1860-1941) - był przede wszystkim znanym i cenionym polskim pianistą oraz kompozytorem. Prowadził jednak także ożywioną działalność polityczną i społeczną. Przed wybuchem I wojny światowej przeznaczał znaczne sumy na cele dobroczynne i publiczne. Po wybuchu wojny rozpoczął owocną działalność dyplomatyczną, mającą na celu zainteresowanie problematyką polską opinii międzynarodowej. Zorganizował ponad 300 wieców i spotkań połączonych z koncertami. W latach 1917-1918 był przedstawicielem paryskiego Komitetu Narodowego Polskiego w USA. Zajął się również organizacją polskich ochotniczych oddziałów wojskowych. Ta działalność polityczno-społeczna dodatkowo umocniła pozycję Paderewskiego na arenie polskiej i międzynarodowej. Jego nazwisko zostało upamiętnione w hodonimach z siedemnastu nazw wojewódzkich. Są to: piętnaście nazw ulic (Bydgoszcz, Gdańsk, Gorzów Wielkopolski, Katowice, Kielce, Kraków, Lublin, Łódź, Olsztyn, Opole, Poznań, Rzeszów, Szczecin, Toruń, Warszawa) i dwie nazwy alei (Białystok, Wrocław). 
- Władysław Raczkiewicz (1885-1947) - prawnik, działacz polityczno-społeczny, prezydent Rzeczypospolitej Polskiej na uchodźstwie. Na początku wojny służył w armii rosyjskiej. Potem organizował jednostki polskie w Rosji i został wybrany na przewodniczącego Naczelnego Polskiego Komitetu Wojskowego (Naczpolu). W 1918 roku sprawował funkcję prezesa Rady Naczelnej Polskiej Siły Zbrojnej, działającej konspiracyjnie w Kijowie. Jego nazwisko stało się podstawą nazw ulic w trzech miastach wojewódzkich: Krakowie, Lublinie i Warszawie.

- Walery Sławek (1879-1939) - polityk, trzykrotny premier Polski, marszałek sejmu Rzeczypospolitej Polskiej. Był bliskim współpracownikiem Piłsudskiego, pomagał mu w tworzeniu Legionów Polskich, Polskiej Organizacji Wojskowej. Po kryzysie przysięgowym został aresztowany przez Niemców. Zwolniono go w listopadzie 1918 roku. Jego postać została upamiętniona w nazwach ulic w czterech miastach wojewódzkich: Katowicach, Krakowie, Warszawie i Wrocławiu.

- Wacław Sieroszewski (1858-1945) - polski pisarz, podróżnik, działacz niepodległościowy, zwolennik Piłsudskiego. W czasie I wojny światowej był żołnierzem Legionów Polskich. Nazwy ulic upamiętniające tę postać znajdują się w trzech miastach wojewódzkich: Krakowie, Lublinie i Warszawie.

- Stanisław Wojciechowski (1869-1953) - polityk, który na początku wojny wraz z Władysławem Grabskim założył w Rosji Centralny Komitet Obywatelski Królestwa Polskiego. Był członkiem Komitetu Narodowego Polskiego. Po rewolucji lutowej stanął na czele Rady Polskiego Zjednoczenia Międzypartyjnego w Moskwie. W toponimii miejskiej funkcjonują tylko nazwy ulic motywowane nazwiskiem tej postaci i znajdują się one w siedmiu miastach wojewódzkich: Bydgoszczy, Gorzowie Wielkopolskim, Krakowie, Poznaniu, Rzeszowie, Szczecinie i Warszawie.

W grupie drugiej warto zwrócić uwagę na hodonimy, których podstawę stanowią nazwiska osób związanych z daną miejscowością. Nie były one dotąd omawiane ze względu na niską frekwencję. Należy jednak odnotować ten typ. Na przykład w Bydgoszczy do takich nazw można zaliczyć ul. Jana Biziela (dr Jan Biziel, 1858-1943, lekarz, działacz narodowy, radny miejski - Czachorowska, Czaplicka-Jedlikowska, Jaracz, Paluszak-Bronka 2008: 44). Z Łodzią był związany m.in. Aleksander Napiórkowski (1890-1920) - działacz niepodległościowy, czynny członek łódzkiego PPS-u, redaktor „Łodzianina”, który poległ w szarży ułańskiej pod Ciechanowem w 1920 roku. Nazwa ulicy upamiętniającej tę postać, jak podają autorki Nazewnictwa miejskiego Łodzi, jest dodatkowo motywowana faktem, że przy niej właśnie mieszkał patron (Bieńkowska, Umińska-Tytoń 2013: 109-110).

Oprócz hodonimów opartych na antroponimach polskich w omawianej grupie można też wskazać formy utworzone od nazwisk cudzoziemskich:

- Ferdynand Foch (1851-1929) - francuski dowódca i teoretyk wojskowy. W czasie I wojny światowej wsławił się kilkoma ważnymi wygranymi, m.in. pod Marną, Ypres, nad Sommą. W 1917 roku został szefem sztabu generalnego, a później - naczelnym wodzem sił sprzymierzonych. Jego nazwisko stało się podstawą nazw ulic w czterech miastach wojewódzkich: Bydgoszczy, Gdańsku, Krakowie i Warszawie. W Kielcach istniała na przykład ul. Marszałka Focha, ale zmieniono ją w 1949 roku na ul. Mariana Buczka (Kopertowska 2001: 79).

- Thomas Woodrow Wilson (1856-1924) - prezydent Stanów Zjednoczonych w latach 1913-1921, który w styczniu 1918 roku wystąpił z programem (zwanym 
„14 punktami”), dotyczącym celów wojennych państw ententy, warunków traktatu pokojowego, kończącego I wojnę światową, oraz zasad przyszłego stałego i trwałego pokoju. Jeden z punktów zakładał utworzenie niepodległej Polski ze swobodnym i bezpiecznym dostępem do morza. Ten program stał się podstawą traktatu wersalskiego. Nazwisko tego prezydenta Stanów Zjednoczonych zostało upamiętnione w hodonimach znajdujących się w trzech miastach wojewódzkich. Są to dwie nazwy ulic (Łódź, Opole) i jedna nazwa placu (Warszawa).

Przywołane powyżej onimy reprezentują dominujący we współczesnej polskiej toponimii miejskiej typ nazw motywowanych antroponimami. Mają one charakter pamiątkowy. Powstały w celu uczczenia postaci, ich dokonań. Wśród nich można wskazać osoby powszechnie znane i cenione (np. Józefa Piłsudskiego, Ignacego Paderewskiego), jak i działaczy lokalnych (np. Jana Biziela, Aleksandra Napiórkowskiego). Jak już wcześniej wspomniałam, motywacją upamiętnienia tych postaci nie był tylko ich udział w I wojnie światowej, ale również wcześniejsze lub późniejsze dokonania, zwłaszcza w przypadku osób zaliczonych do grupy drugiej. Zresztą ich udział w tym wydarzeniu historycznym był różny. Jedni odegrali większą, a inni mniejszą rolę. Jedni bezpośrednio uczestniczyli w walkach, inni - prowadzili działalność polityczną na rzecz odrodzenia ojczyzny. Dla każdego z nich ta wojna była jednak ważnym doświadczeniem.

I wojna światowa to wydarzenie, które z pewnością zasługiwało na upamiętnienie. Przeprowadzona analiza wykazała, że ten fakt dziejowy został odzwierciedlony w wielu różnorodnych polskich hodonimach, a zwłaszcza nazwach motywowanych nazwiskami osób, które brały udział w tej wojnie (bezpośrednio lub pośrednio), przyczyniając się do odzyskania wolności oraz stworzenia niepodległego państwa. W przypadku onimów zaliczonych do drugiej grupy należy pamiętać o tym, że są one pośrednio związane z omawianym zagadnieniem. Wiele nazw miejskich utworzono również od daty 11 listopada 1918 roku, stanowiącej przełom w dziejach Polski, a także od określeń: niepodległość, wolność, związanych z tym dniem. Mniej hodonimów pochodzi natomiast od nazw formacji, organizacji wojskowych i patronów grupowych, a także miejscowości, w okolicy których stoczono walki w czasie wojny.

Przedstawione $\mathrm{w}$ niniejszym artykule nazwy pamiątkowe stanowią pewien rodzaj pamięci, są swego rodzaju kroniką, w której zapisane zostały m.in. fakty z historii narodowej, informacje o osobach zasłużonych dla naszej ojczyzny. Myślę, że 100-lecie zakończenia I wojny światowej jest dobrym pretekstem, aby przybliżyć tę przeszłość zapisaną w hodonimach, zwłaszcza że - jak pisała Maria Biolik - „Patronowie ulic i placów nie są najczęściej znani mieszkańcom miasta. Nazwa ulicy nie kojarzy im się więc z konkretną mniej lub bardziej wybitną osobą, którą upamiętnia, a jedynie z ulicą, do lokalizacji której nie są potrzebne dodatkowe informacje dotyczące osoby upamiętnianej” (Biolik 1982: 56).

\section{Bibliografia}

Antkowiak Z., 1970, Ulice i place Wrocławia, Wrocław.

Antkowiak Z., 1982, Patroni ulic Wrocławia, Wrocław.

Belchnerowska A., 1994, Nazewnictwo miejskie Szczecina, w: Synchroniczne i diachroniczne aspekty badań polszczyzny, t. I, red. M. Białoskórska, S. Kania, Szczecin, s. 167-170. 
Bieńkowska D., Umińska-Tytoń E., 2013, Nazewnictwo miejskie Łodzi, wyd. 2 poprawione i uzupełnione, Łódź.

Biolik M., 1982, Typy semantyczne współczesnych nazw ulic i placów Olsztyna, „Komunikaty Mazursko-Warmińskie" XXVI, nr 1-2, s. 51-61.

Buczyński M., 1966, Nazwy ulic i placów Lublina, „Onomastica”, t. XI, z. 1, s. 136-181.

Ciepłowski S. (red.), 2002, Stownik patronów ulic Warszawy, Warszawa.

Cygan W.K., 1992, Słownik biograficzny oficerów Legionów Polskich, t. 1, Warszawa.

Czachorowska M., Czaplicka-Jedlikowska M., Jaracz M., Paluszak-Bronka A., 2008, Słownik toponimów miejskich Bydgoszczy, Bydgoszcz.

Czech J. (oprac.), 1995, Ulice Opola, Opole.

Gąsiorowski A., 1984, Nazwy poznańskich ulic. Przemiany i trwanie: wiek XIV-XX, „Kronika Miasta Poznania" LII/ 3-4, s. 23-64.

Gierszowski S. (red.), 1997, Pomorscy patroni Trójmiasta, Wrocław.

Handke K., 1970, Typy semantyczne i strukturalne nazw ulic Warszawy, Wrocław-Warszawa-Kraków.

Handke K., 1998, Przemiany w polskim nazewnictwie miejskim ostatniego pótwiecza jako obraz działań pragmatycznych, w: Najnowsze przemiany nazewnicze, red. E. Jakus-Borkowa i K. Nowik, Warszawa, s. 39-45.

Handke K., 1998, Stownik nazewnictwa Warszawy, Warszawa.

Handke K., 2004, Nazewnictwo miejskie - składnik edukacji społecznej, w: Nazwy własne w języku, kulturze i komunikacji społecznej, red. R. Mrózek, Katowice, s. 89-97.

Kopertowska D., 2001, Kielce. Historia i współczesność w nazewnictwie, Kielce.

Jurkiewicz J.L., 1999, Patroni szczecińskich ulic (Leksykon), Stargard.

Liskowacki A.D., 1995, Ulice Szczecina, Szczecin.

Myszka A., 2016, Urbanonimia Rzeszowa: językowo-kulturowy obraz miasta, Rzeszów.

NEP - Nowa encyklopedia powszechna PWN, t. 1-8, wyd. 2 poszerz. i zm., Warszawa 2004.

Nosowicz J.F., 2000, Z badań nad nazewnictwem ulic Biategostoku, w: Białystok w 80-leciu. W rocznice odzyskania niepodległości 19 II 1919-19 II 1999, Białystok, s. 195-210.

Rzewiczok U., 1997, Patronowie katowickich ulic, Katowice.

Supranowicz E., 1995, Nazwy ulic Krakowa, Kraków.

w1 - https://onomastyka.uni.lodz.pl/strona-glowna/terminologia-polska (dostęp: 24.03.2018).

WE - Wielka encyklopedia powszechna PWN, t. 1-12, Warszawa 1965-1969.

WEP - Wielka encyklopedia PWN, t. 1-30, Warszawa 2001-2005.

Wrzosek M., 1990, Polski czyn zbrojny podczas pierwszej wojny światowej 1914-1918, Warszawa.

Zysnarski J., 2007, Od Abdeckerei do Żwirowej, czyli klucz do toponomastyki Gorzowa, „Nadwarciański Rocznik Historyczno-Archiwalny" 14, s. 31-70.

Żuraszek-Ryś I., Macutkiewicz B., 2001, Nazewnictwo miejskie Zielonej Góry, w: Zielonogórskie seminaria polonistyczne, red. S. Borawski, J. Brzeziński, Zielona Góra, s. 489-507.

\section{IWONA ŻURASZEK-RYŚ}

\section{Polish hodonyms commemorating WWI}

\section{Summary}

WWI has been among the most important events in the history of Poland. After many years of submission, Poles regained the much coveted freedom and were able to establish an independent country. The question arises 
if this significant historical fact was reflected in the names of streets, alleys, squares or housing estates of Polish cities. The purpose of this article provides a response to the question. Another important issue is a definition of the types of names commemorating this significant historical event.

Keywords: hodonyms, commemorative city names, types of names commemorating WWI 